\title{
Application of Specific Eco-Exergy to FAO Fisheries Data
}

\author{
Lisa Kernegger ${ }^{1}$, Jacob Carstensen ${ }^{2}$ and José-Manuel Zaldívar ${ }^{1, *}$ \\ ${ }^{l}$ European Commission, Joint Research Centre, Institute for Environment and Sustainability, Ispra (VA), Italy; ${ }^{2} \mathrm{Na}-$ \\ tional Environmental Research Institute (NERI), Roskilde, Denmark
}

\begin{abstract}
We have applied specific eco-exergy to data on fisheries landing and on aquaculture from FAO. Specific ecoexergy gives a weight to each species, depending on the genetic information content. The biomass for each species is multiplied by this factor and then the sum of all values divided by the total biomass. Therefore, this value is independent of the total catches and reflects the quality in terms of information content of what we are extracting from the whole oceans or producing by aquaculture. The objective was to analyze the trends of this indicator. In addition, we have detected possible change points in the gradient at unknown times using likelihood ratio test, with the null hypothesis of linear relationship. We intended to analyze these detected change points against well-known historical events in all defined FAO areas. The results show a continuous decline, since the 70's, for the world marine specific eco-exergy. On the contrary, the same analysis applied to aquaculture shows no decreasing trend.
\end{abstract}

\section{INTRODUCTION}

Industrialized fishing is rapidly depleting fish stocks and some commercial fisheries worldwide are being driven to collapse [1-2]. In addition, marine biodiversity loss is affecting marine ecosystem functions at all scales [3]. At the beginning, fisheries stock assessment and management was based on single-species population models using fisheries catch and effort as input [4]. After, different stock assessment techniques has been developed depending on the availability and accuracy of data, see for example [5-8]. However, these approaches have not been able to stop the decline in fisheries and for these reasons, an ecosystem approach to manage fisheries has been proposed [9] where fish populations are considered as part of the marine ecosystem. This approach based on population and ecosystem dynamics is aiming to avoid cascading/secondary effects [10] and destruction of marine ecosystems. However, in order to develop this approach, there is still the need to develop techniques for fisheries management assessment consistent with the ecosystem view.

Another idea that has gained recognition during the last decades in ecological systems is the existence of thresholds: a critical value of a pressure beyond which a state indicator shifts to a different regime [11-12]. The existence of such thresholds has been suggested to be used as a conceptual framework for the development of strategies for sustainable management of natural resources [13-14]. Even though, the concept of thresholds has been for a long time embedded in ecological risk assessment [15], starting from the doseresponse curve, the number of experimental cases for which a threshold of regime shift have been unequivocally detected is still low [16]. Even though fish population collapses are one of the most referred examples; attributed, normally, to a combination of fisheries pressure and change of environmental conditions [17-19].

*Address correspondence to this author at the European Commission, Joint Research Centre, Institute for Environment and Sustainability, Ispra (VA), Italy; Tel: +39-0332789202; Fax: +39-0332-785807;

E-mail: jose.zaldivar-comenges@jrc.it
In this framework we have applied an ecosystem indicator: specific eco-exergy [20] to fish landing historical datasets [21]. The objective was to analyze the results provided by this indicator as well as the possible existence of regime shifts in these data sets by applying a statistical method to detect changes in time series trends. This approach intends to help in developing a strategy for fisheries ecosystem-based management by providing a global metric to examine ecosystem status. However, it is still in the preliminary phases and therefore several developments concerning its application for fish species are still needed.

\section{MATERIALS AND METHODS}

\section{Eco-Exergy and SPECIFIC ECO-EXERGY}

The central problem of ecology concerns the relationships of individual organisms with their environment, the interactions and diversity of species and the fluxes of energy and materials through ecosystems. All levels of ecological organisation, from individual organisms to assemblages of species to ecosystems to the entire biosphere, are examples of complex systems with their typical features i.e. ecological systems are comprised of many parts; they are open systems that maintain themselves far from equilibrium by the uptake and transformation of energy and by exchange of organisms and matter across their boundaries; they are adaptive, responding to changing environments; they have irreversible histories; and, consequently, they exhibit a rich variety of complex, non-linear dynamics.

In order to try to characterize ecosystems form a nonequilibrium thermodynamics point of view, Jørgensen and co-workers [20] have introduced and developed during the last 20 years the concept of eco-exergy. Eco-exergy is defined as the amount of work a system can perform when it is brought to thermodynamic equilibrium with its environment or reference state, defined as the inorganic soup on earth 4 billion years ago. From this definition is easy to see that ecoexergy depends on the state of the total system (ecosystem plus reservoir/environment) and, hence, it is not a state variable. The eco-exergy (Ex) of an ecosystem cannot be meas- 
ured, but may be computed for each system component by multiplying its concentration, $c_{i}$, measured in terms of its average standing biomass, with its genetic information content, $\beta_{i}$, using conversion factors:

$$
\frac{E x}{R T}=\sum_{i=1}^{n} \beta_{i} \cdot c_{i}
$$

where $R$ is the ideal gas constant, T the temperature Related to the eco-exergy concept, Jørgensen and co-workers [20] introduced the concept of specific (or structural) eco-exergy, which is the eco-exergy calculated relatively to the total biomass:

$$
\frac{E x_{s t}}{R T}=\sum \beta_{i} \frac{c_{i}}{c_{t}}
$$

where $c_{t}$ is the total biomass concentration, which is the sum of all $c_{i}$ including inorganic matter available to growth of biomass. Specific eco-exergy expresses the dominance of the complex organisms - going from humans, $\beta=2173$, to virus, $\beta=1.01$ [22]- because, per unit biomass, they carry more information, that is, they have higher $\beta$-values. For example, a very eutrophic aquatic ecosystem will have a very high eco-exergy due to the large biomass, but the specific ecoexergy will be low, as the biomass will be dominated by species with low $\beta$-values, i.e. phytoplankton, $\beta=20$. The combination of the eco-exergy and specific eco-exergy index usually gives a more satisfactory description of the health of an ecosystem than the eco-exergy index alone, because it considers diversity and life conditions for higher organisms.

However, one of the main problems in the real application of eco-exergy has been the development of a procedure to calculate the values of $\beta$. Jørgensen [20] proposed to take into account the number of genes to calculate this value. As the data on the total number of genes for many organisms are becoming available, the original difficulties on using this approach have decreased. Recently, it has been proposed [23] an operational approach by using the haploid nuclear DNA contents of organisms (C-values). The nuclear DNA content in picograms (pg), which correspond to a certain number of base-pairs (bp) in the DNA ( $\left.1 \mathrm{pg}=0.98 .10^{9} \mathrm{bp}\right)$, $2 \mathrm{C}$, is divided by 2 to give the number of nucleotides in one polynucleotide chain (one DNA strand). Under the assumption that, for each adjacent triplet of nucleotides in nonrepetitive DNA corresponds a transcribed RNA-signal, this number is then divided again by 3 to give the number of nucleotide triplets (maximum coding capacity. Then $\beta$ is calculated as [23]:

$$
\beta=1+\frac{\ln 20^{(C / 3)}}{7.34 \cdot 10^{5}}
$$

whereas the value $7.34 .10^{5}$ is used to normalize all values in terms of detritus. However, there exists the problem of the 'C-value paradox' [24], which is based on the fact that some organisms with less morphological complexity than mammals exhibit larger C-values, evidencing a lack of correlation between structural complexity and total DNA content. Therefore, it was proposed in [23] to calculate $\beta$, for each species, using the known lowest $\mathrm{C}$-value. In addition, in a new calculation scheme, using several approaches [22], it was observed that by subtracting the value of the percentage of repeating sequences better correlation were obtained and uncertainty was reduced. Then $\beta$ was calculated as:

$$
\beta=1+\frac{\ln 20^{[C(1-\text { number of repeating genes }) / 3]}}{7.34 \cdot 10^{5}}
$$

Using this approach, the number of $\beta$ values was extended from 16 to 56 [22]. However, the level of definition is still high compared with the indicators normally developed for assessing ecological status based on specific species, assemblages or ratios between classes of organisms [25]. In a recent study, a more detailed approach was followed to assess the environmental status on coastal lagoons based on macrophytes data [26]. In this case, it was possible to calculate $\beta$-values for 244 seaweed and seagrass species common in Mediterranean coastal lagoons. The values obtained using specific eco-exergy were compared with macrophyte-based indicators recently proposed [27-29] and similar results of classification levels were obtained. This approach was also carried out for macrobenthos with a general agreement with other ecological indicators. However, the calculation of $\beta$ values presented higher variability and uncertainty [31]. When the approach was applied to FAO datasets we found that they were not sufficiently specific to move to a deeper level than organism and $2 \mathrm{C}$ values for fish species shown a high variability when compared with macrophyte and even macrobenthos data. For the specific case of macrophytes this is probably due to the fact that practically all $2 \mathrm{C}$ values for them were obtained from a single reference [30]. For this reason, the last values proposed in [22] have been employed in this work, see Table 1. Even though, this is a crude approximation since we are working at a high organisms level, the values obtained are compared between themselves. This relative comparison is the approach recommended in [20] when working with specific eco-exergy.

Table 1. $\beta$-Values Used in this Work, see Table 3 in [22].

\begin{tabular}{|c|c|}
\hline Organism & Conversion Factor $(\boldsymbol{\beta})$ \\
\hline \hline Cnidaria & 91 \\
\hline Mollusc & 310 \\
\hline Crustacean & 232 \\
\hline Chordata & 246 \\
\hline Fish & 499 \\
\hline
\end{tabular}

\section{FAO Landing Data and FAO Areas}

The FAO global statistics [21] were used to obtain landing statistics of fisheries and aquaculture production of Mariculture and Brackishwater culture from 1950 to 2003, see Fig. 1. The FAO Fishing areas are divided into 27 major fishing areas: 8 enclosed and 19 marine areas, see Fig. 2. The marine areas are covering the waters of the Atlantic, Indian Pacific and Southern Oceans, with their adjacent seas. Following the approach proposed by Pauly et al. [32], FAO fishing areas were grouped into 9 regions. 

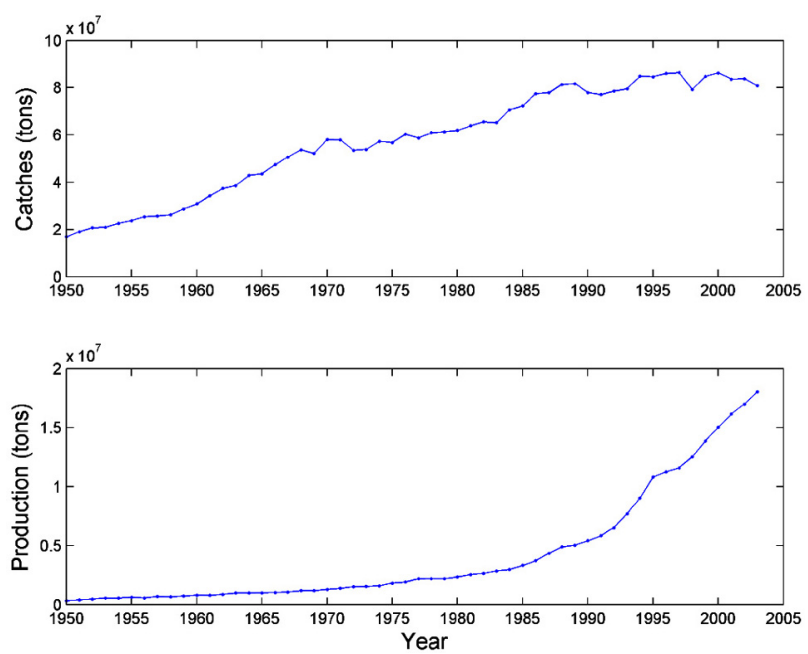

Fig. (1). a/ Global marine catches; b/Aquaculture production.

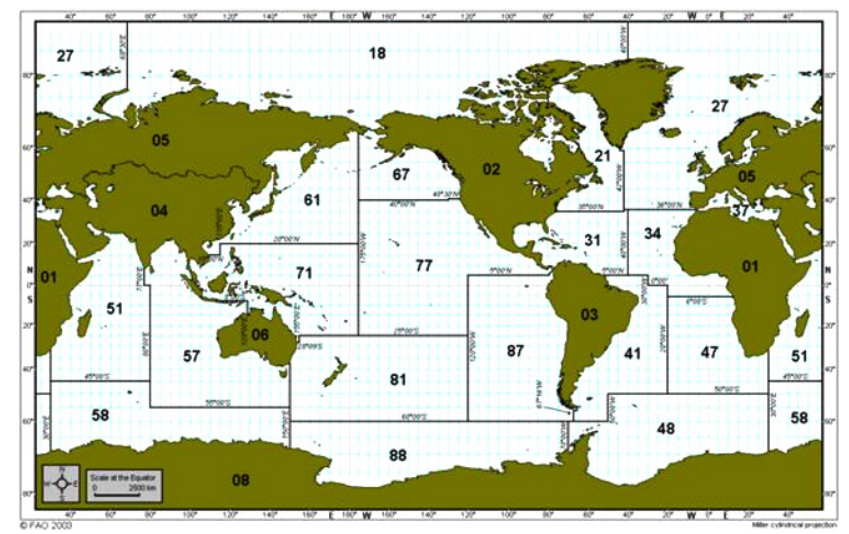

Fig. (2). FAO map of the major fishing areas of the world. Source: www.fao.org.

The total biomass used for the specific eco-exergy calculation is the sum of all catches per area per year excluding catches under one tonne, plants and catches that were not stated in tonnes like seals, whales and crocodriles.

The FAO statistics are on different taxonomic levels. Over $30 \%$ of all marine landings cannot be identified to the species level, and about $20 \%$ cannot even be assigned to the level of Family [33]. Therefore we chose to use $\beta$ values on the Phylum level presented by [22]. For the calculation of specific eco-exergy the $\beta$ values used were for Mollusca and Cnidaria. As Crustaceans are the most important Arthropoda for commercial fisheries we used a $\beta$ value for the Subphylum Crustacea. Chordata beta values were used for all Chordatas but Fish, for which a separate $\beta$ value was used. Consequently data that could not be classified into the phyla used (like aquatic invertebrates) and data for which no $\beta$ value could be found in the table were not used for calculations. However, the biomass considered accounts approximately for $80 \%$ of the total biomass in the datasets. Even though problems with China reports to FAO have been discussed [34], we have not excluded their data from this analysis.

\section{Identification of Change Points}

Time series of specific eco-exergy (global catches, region-specific catches and aquaculture, $X_{t}$ ) were examined for changes in trends occurring at unknown points in time. This was done by first assuming a linear trend and then adding a change point in time as an unknown parameter, where the trend coefficient changes.

$$
X_{t}=\left\{\begin{array}{c}
\mu+\beta \cdot t \quad t<k \\
\mu+\beta \cdot t+\delta(t-k) \quad t \geq k
\end{array}\right.
$$

In this case, the null hypothesis is $\delta=0\left(H_{0}\right)$ and the alternative hypothesis is $\delta \neq 0\left(H_{l}\right)$. The change point can be viewed as a knot where two lines join. Adding a change point increases the model degrees of freedom by 2 , since both the point in time and the change in trend coefficient are unknown parameters. The time series were investigated for up to 5 change points ( 6 connected line-pieces), and higher order models were compared to lower order models by means of likelihood ratio $(L R)$ test [35]:

$$
L R=\Lambda=\frac{H_{0}}{H_{1}}
$$

The distribution of $L R$ is generally unknown, but when the number of points tends to infinity $-2 \log (\Lambda)$ is asymptotically $\chi^{2}$-distributed with degrees of freedom equal to the difference in free parameters between the two models [35]. The non-linear models were estimated by maximizing the likelihood function. The statistical analyses were carried out using PROC MODEL in SAS.

\section{RESULTS AND DISCUSSION}

\section{Global Marine Catches and Global Aquaculture}

The results of the calculation of specific eco-exergy for global marine fisheries landing data and global aquaculture are shown in Fig. 3. There was an increase of specific ecoexergy of global catches until 1966, then the average specific eco-exergy stabilizes until 1971 and after there is a continuous decrease, which seems to accelerate after 1995. Specific eco-exergy gives a weight to each species, depending on the genetic information content. The biomass for each species is multiplied by its $\beta$ factor and then the sum of all values divided by the total biomass. Therefore, this value is independent of the total catches, and reflects the quality in terms of information content of what we are extracting from the whole oceans. However, it is possible to observe that this value reflects the World fisheries trends in landings, with an exponential growth period until 1971 followed by a change in the trend around 1971, see Fig. 1. This is in accordance with the results from [32] that pointed out that there is a general decline in mean trophic level of marine and inland landings. The change in trend at the beginning of the 70's may be attributed to the fact that a collapse of large valuable stocks occurred during these years (e.g. the Peruvian anchoveta, Southern African pilchard fisheries) which will explain the phenomenon of change in catch composition as "fishing down marine food webs" [32]. Also during these years appeared the Law of the Sea and the 200 nautical miles into the open sea as exclusive economic zones of maritime countries [36]. 

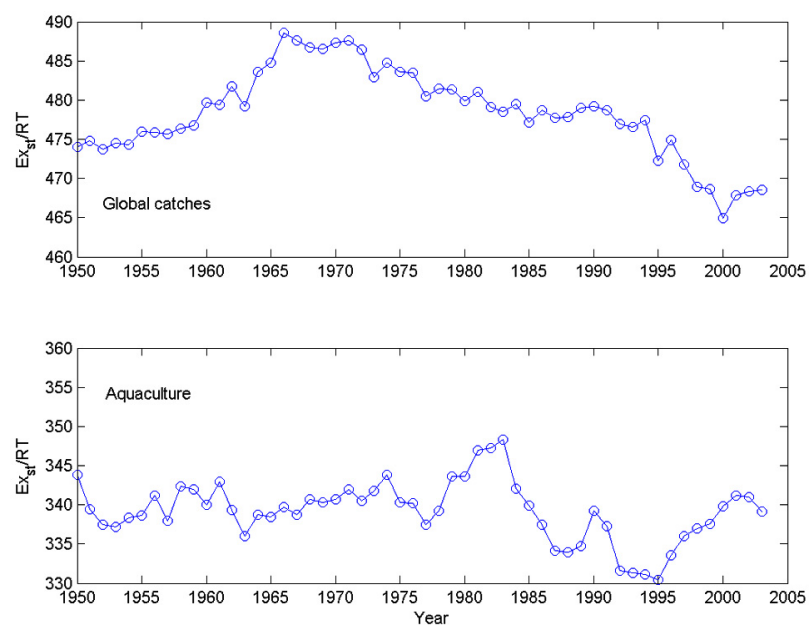

Fig. (3). Specific eco-exergy time series eco-exergy for: a/ global marine catches; b/aquaculture.

The same approach was used to analyze the aquaculture production data (Fig 3, bottom). Even though there has been a continuous increase in aquaculture production since its beginnings, see Fig. 1, the specific eco-exergy shows a different behaviour than global marine catches with lower specific eco-exergy values and with no decreasing trend.

It is clear that by using landing data we assume that changes in the landing data reflect changes in the marine ecosystem which is not true. In addition, we are analysing the data without taking into consideration natural variability and fluctuations in population's size [33] due to climatic variability. Furthermore, other aspects embedded in the datasets are related to technical efficiency, e.g. use of fish detection devices, and to economic aspects such as the market price for fish and/or legal, e.g. regulations or fish quotas [36]. However, with the industrial development and globalization of fisheries during the last decades it is difficult to believe that landing data do not reflect the relative magnitudes of existing biomasses in the World Seas. These results confirm the analysis from [32] based on the mean trophic level of the species which was criticized in [33] based on the fact that the assignation of a mean trophic level was somewhat arbitrary.

This decreasing trend is typical of a throphic cascade at global level as reported in [19] for the large eastern Scotian Shelf ecosystem off Nova Scotia (Canada) were decreases in top predator abundance Cod $\left(\mathrm{Ex}_{\mathrm{st}}=499\right)$, attributed to a combination of fishing pressure and climatic changes, produced a cascading effect and an increase in lower thropic levels such as shrimps and crabs $\left(E x_{s t}=232\right)$. Following the data form [37], the calculated change of $E x_{s t}$ was from 489 in 1985 to 378 in 1997, which is higher than the values obtained for aquaculture.
In addition, the differences between the values found for aquaculture production in terms of lower specific eco-exergy values and the absence of clear trends point out that the specific eco-exergy is able to extract relevant information concerning the status of the fisheries. If both series would have show similar values, i.e. natural versus man-made system, and behaviour then $E x_{s t}$ would have not provided useful information.

\section{Statistical Analysis of Specific Eco-Exergy Time Series}

Time series were analysed for change-points, where the gradient changed. This method tries to detect when a change in a time series has occurred based on a change in the gradient. The main results are presented in Table 2 and Figs. 4-5.

The change points obtained for global fisheries (fig. 4) using specific eco-exergy show an increase of specific ecoexergy until the late1960s, with a slower increase from the 1950s till 1959 and a faster increase from after 1959 till the late 1960s. As said before, this rapid increase in specific ecoexergy probably reflects the growth of industrialized fishing. After 1968 specific eco-exergy started to decline with a short period of stabilization from 1984 till 1991, approximately zero slope. The decline of $E x_{s t}$ around 1970 reflects probably the collapse of several important fisheries.

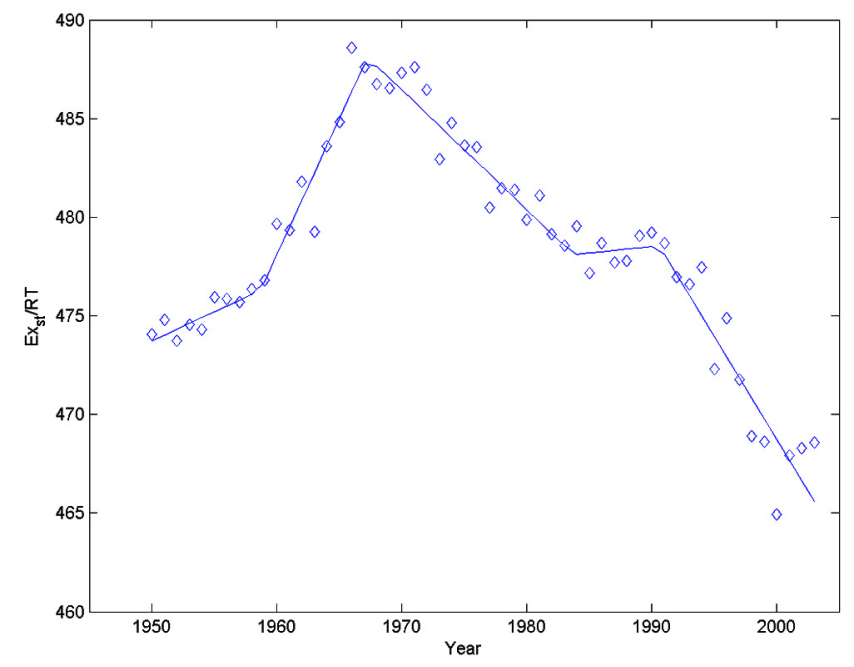

Fig. (4). Change-points in specific eco-exergy time series for global marine catches.

Specific eco-exergy for aquaculture data shows lower values of specific eco-exergy and a different pattern. According to the change point detection analysis, see fig. 5, there was a slow decrease from 1950 till the mid 1960s, followed by an increase till the beginning of the 1980s and a sharp decline till the mid 1990s, recovered afterwards. The low mean value of specific eco-exergy is probably due to the fact that mollusc aquaculture represents an important contribution to the total biomass when compared with global fisheries. In fact, it was reported in [38] that only $7 \%$ of mariculture production consists on carnivorous fish (e.g. salmon, bass, bream, etc.) whereas $48 \%$ is centred on invertebrate filter feeders (e.g. mussels, oysters, scallops, clams, etc.). 


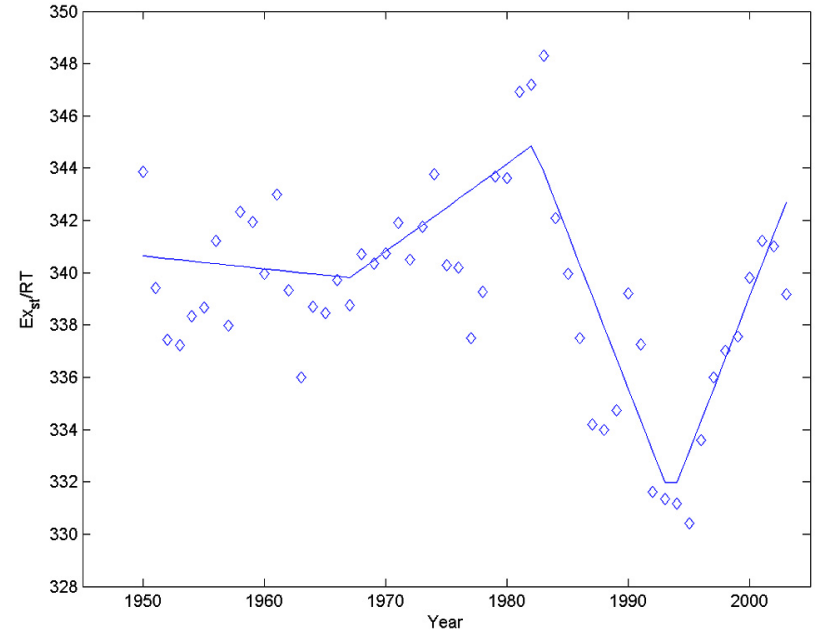

Fig. (5). Change-points in specific eco-exergy time series for aquaculture.

If we compare specific eco-exergy values for both groups (global fisheries and aquaculture) and we extrapolate linearly the global fisheries decreasing trend obtained after linear regression in the last part of the data set, we obtain that in approximately 125 years, specific eco-exergy for both systems will be similar. If this trend could be attributed to changing market demand we should be able to observe a similar behaviour in aquaculture production data.

In this sense our approach is in line with the results from [3] that predicted the fisheries collapse by the year 2048. As all extrapolation results, care should take in the interpretation [39-41] and they should be interpreted as a worse case scenario, since it is expected that fisheries policy would adapt to maintain a sustainable exploitation.

Figure 6 shows the results from the different FAO areas grouped following [32]. Concerning the North Pacific (FAO areas 61 and 67), it seems that from the beginning of the observed time period till $1963 E x_{s t}$ was approximately constant. From 1963 to the late 1960 s $E x_{s t}$ increased rapidly, followed by a slow decrease until beginning of 1990s where the negative slope increased considerably. The decrease of $E x_{s t}$ in the early 1990 s coincides with the decrease in landings of Alaskan Pollock in the early 1990s and the collapse of Japanese pilchard (sardine) in the late 1980s in the Northwest pacific as well as the increase in mollusc landings around this period. In 1994 the total amount of squids, cuttlefish and octopuses landed in the Northwest Pacific (FAO area 61) reached an all time high of about $958000 \mathrm{t}$ [42].

The FAO area 27 (Northeast Atlantic) shows small oscillations until the late 1970s but with approximately constant values. During this period Iceland expanded its fishing jurisdictions from 3 (before 1952) to 200 (1976) nautical miles off the coast of Iceland. This period has been called the "Anglo-Icelandic Cod war" [16] and even though the environmental resources did not change, there was a social regime shift in the British fishing industry. Because this area has a long fishing history most of the traditional fishery resources of the Northeast Atlantic are fully or overexploited, with several stocks in a depleted condition [42]. The biggest total biomass landings in this area were in 1976. It was around this time that $E x_{s t}$ started to decline. Few species have been
Table 2. Maximum Log-Likelihood for 11 Different Specific Eco-Exergy Variables Analysed by Means of 4 Different Models with Increasing Complexity. Coefficients of Determination are Given in Parentheses. $\mathrm{NC}=$ Not Converged

\begin{tabular}{|c|c|c|c|c|}
\hline \multirow[b]{2}{*}{ Variable } & \multicolumn{4}{|c|}{ LogLikelihood and $\mathbf{R}^{2}$ (in Parentheses) Values } \\
\hline & $\begin{array}{l}\text { Linear } \\
\text { trend - no } \\
\text { change- } \\
\text { point }\end{array}$ & $\begin{array}{c}\text { Linear } \\
\text { trends - } 1 \\
\text { change- } \\
\text { point }\end{array}$ & $\begin{array}{l}\text { Linear } \\
\text { trends - } 2 \\
\text { change- } \\
\text { points }\end{array}$ & $\begin{array}{c}\text { Linear } \\
\text { trends - } 3 \\
\text { change- } \\
\text { points }\end{array}$ \\
\hline Total & $\begin{array}{c}-164.68 \\
(0.16)\end{array}$ & $\begin{array}{c}-109.85 \\
(0.89)\end{array}$ & $\begin{array}{c}-109.85 \\
(0.89)\end{array}$ & $\begin{array}{l}-97.46 \\
(0.93)\end{array}$ \\
\hline Aquaculture & $\begin{array}{c}-146.20 \\
(0.09)\end{array}$ & $\mathrm{NC}(0.20)$ & $\mathrm{NC}(0.63)$ & $\begin{array}{c}-119.15 \\
(0.66)\end{array}$ \\
\hline $\begin{array}{c}\text { FAO } 61 \& \\
67\end{array}$ & $\begin{array}{c}-214.08 \\
(0.00)\end{array}$ & $\begin{array}{c}-174.32 \\
(0.77)\end{array}$ & $\mathrm{NC}(0.86)$ & $\mathrm{NC}(0.92)$ \\
\hline $\begin{array}{c}\text { FAO } 21 \& \\
31\end{array}$ & $\begin{array}{c}-203.05 \\
(0.75)\end{array}$ & $\begin{array}{c}-159.86 \\
(0.95)\end{array}$ & $\mathrm{NC}(0.96)$ & $\begin{array}{c}-137.75 \\
(0.98)\end{array}$ \\
\hline FAO 27 & $\begin{array}{c}-101.57 \\
(0.73)\end{array}$ & $\begin{array}{l}-91.63 \\
(0.81)\end{array}$ & $\begin{array}{l}-50.80 \\
(0.96)\end{array}$ & $\begin{array}{c}-51.13 * \\
(0.96)\end{array}$ \\
\hline FAO 37 & $\begin{array}{c}-166.54 \\
(0.04)\end{array}$ & $\begin{array}{c}-155.34 \\
(0.36)\end{array}$ & $\begin{array}{c}-155.34 \\
(0.36)\end{array}$ & $\begin{array}{c}-149.60 \\
(0.49)\end{array}$ \\
\hline FAO 77 & $\begin{array}{c}-204.20 \\
(0.31)\end{array}$ & $\begin{array}{c}-192.72 \\
(0.55)\end{array}$ & $\begin{array}{c}-155.13 \\
(0.89)\end{array}$ & $\mathrm{NC}(0.88)$ \\
\hline $\begin{array}{c}\text { FAO } 41,34 \\
\quad \& 47\end{array}$ & $\begin{array}{c}-162.43 \\
(0.71)\end{array}$ & $\begin{array}{c}-135.79 \\
(0.89)\end{array}$ & $\begin{array}{c}-134.79 \\
(0.89)\end{array}$ & $\begin{array}{c}-123.37 \\
(0.93)\end{array}$ \\
\hline $\begin{array}{c}\text { FAO } 51,57 \\
\& 71\end{array}$ & $\begin{array}{c}-144.07 \\
(0.05)\end{array}$ & $\begin{array}{c}-141.64 \\
(0.13)\end{array}$ & $\begin{array}{c}-117.95 \\
(0.64)\end{array}$ & $\begin{array}{c}-117.95 \\
(0.64)\end{array}$ \\
\hline $\begin{array}{c}\text { FAO } 81 \& \\
87\end{array}$ & $\begin{array}{c}-175.75 \\
(0.29)\end{array}$ & $\begin{array}{c}-136.74 \\
(0.83)\end{array}$ & $\begin{array}{c}-132.29 \\
(0.86)\end{array}$ & $\begin{array}{c}-129.95 \\
(0.87)\end{array}$ \\
\hline $\begin{array}{c}\text { FAO } 48,58 \\
\quad \& 88\end{array}$ & $\begin{array}{c}-160.15 \\
(0.61)\end{array}$ & $\begin{array}{c}-152.28 \\
(0.77)\end{array}$ & $\mathrm{NC}(0.77)$ & $\mathrm{NC}(0.82)$ \\
\hline
\end{tabular}

* Singular covariance matrix.

collapsing or close to collapse since then. For example the North Sea cod stock showed decrease landings since the 1970s. In common with many other fish stocks in the North Sea, cod are heavily exploited with as much as $60 \%$ of fishable stock being removed annually [43]. However since the late 1980s there has been a change in $E x_{s t}$ trend, which shows a slow increase.

$E x_{s t}$ in the Northwest and Western Central Atlantic (FAO area 21 and 31) was increasing till the late 1960s followed by a sharp decline, a plateau in earlier 1980s -slope close to zero- and a decline since then. During these years there have been several reported fish stocks declines. Collie et al. [18] analyzed the time series of biomass of Georges Bank Haddock from 1931 to 2000. During the 1960's biomasses more than doubled and catches increased to over 100 tonnes followed by a biomass collapse after 1965 with a slight increase in the earlier 1980s and a gradual increase from late 1990s [44]. In [45], it is described that since the 1970 there has been a dramatic decline in the abundance of the western At- 

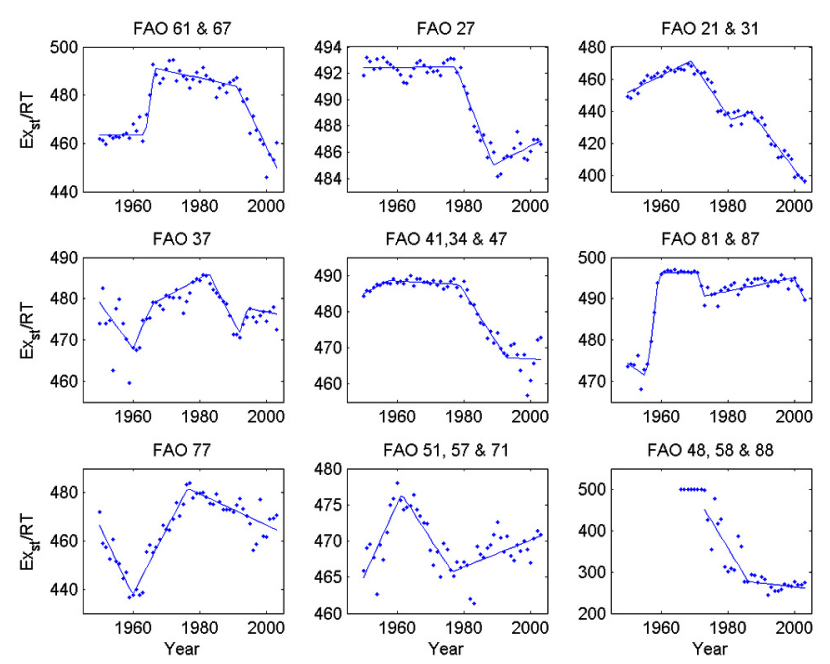

Fig. (6). Change-points in specific eco-exergy time series for FAO areas grouped following [32]: North Pacific (FAO areas 61 and 67); Northeast Atlantic (FAO area 27); Northwest and Western Central Atlantic (FAO area 21 and 31); Mediterranean and Black sea (FAO area 37); Southwest, Central Eastern and Southeast Atlantic (FAO area 41, 34 and 47); South Pacific (FAO area 81 and 87); Central Eastern Pacific (FAO area 77); Indo(west)pacific (FAO areas 51, 57 and 71); and Antarctica (FAO areas 48, 58 and 88 ).

lantic bluefin tuna. One of the worst collapses in the history of fisheries [46-48] is the collapse of northern cod. Furthermore all recorded shark species in the Northwest Atlantic, with the exception of Makos, have declined by more than $50 \%$ in the past 8 to 15 years [49]. The Northwest and Western Atlantic is the area with the second largest total $E x_{s t}$ decline.

The $E x_{s t}$ of total landings from the Mediterranean and Black sea (FAO area 37) decreased from 1950 till around 1960. From 1960 till the late 1960s a rapid increase of $E x_{s t}$ took pace. From the late 1960 till the early 1980s $E x_{s t}$ increased but not as fast as before. The increase of $E x_{s t}$ from the 1960s till the early 1980s coincides with the increased amount of landings and the developing of a commercial fishery; reaching 1.95 million tonnes in 1982 and remained around this level until peaking at 1.97 million tonnes in 1988 [21]. $E x_{s t}$ started decreasing around 1983 with lowest $E x_{s t}$ values in 1992 when the collapse of the Black Sea anchovy and sprat stocks occurred. However, the Black Sea recovered relatively fast from the collapse, probably due to the decrease in nutrient inputs that followed the East Europe changes during the 90s [50]. The slow decrease of specific $E x_{s t}$ values since the mid nineties coincide with prey depletion (mostly small epilagics) and overfishing of marine megafauna like that observed [51] in the Central Mediterranean.

$E x_{s t}$ values in the Southwest, Central Eastern and Southeast Atlantic (FAO area 41, 34 and 47) increased from the beginning of the observed time series till the late 1950s. Until the late 1970 s it stayed more or less stable followed by a decline that started around 1978 in parallel with the decline of Southern African pilchard, Cunene Horse mackerel, Chub mackerel and Cape hakes. Furthermore in the south West Atlantic the landings of Squids, Cuttlefish and Octopus have been increasing since the late 1970s. Specific eco-exergy remained low but stopped declining around 1993.

In the South Pacific (FAO areas 81 and 87), $E x_{s t}$ values increased until 1960 after a short decrease. The low $E x_{s t}$ value from 1950 to 1955 coincides with the fact that in this area the fishing industry was largely for domestic consumption till the 1960s. The increase of specific eco-exergy from the mid 1950s on reflects the growth of a huge fishery for Peruvian anchoveta in the south east Pacific. Catches of anchoveta were above 10 million tonnes in the late 1960 s to 1971 off northern and central Peru. The Peruvian anchoveta population was heavily fished and collapsed during the warming of the 1972 El Niño which is reflected in the time series by the decrease of specific eco-exergy. Specific ecoexergy increased slightly from around 1973 till 2000, followed by a decline.

Specific eco-exergy in the Central Eastern Pacific (FAO area 77) decreased from the 1950s until around 1960s. In this area some pelagic fisheries were already quite developed during the first half of this century. Catches of California pilchard (or sardine) (Sardinops sagax caeruleus) reached peaks well over $700000 \mathrm{t}$ already in the 1930s and early 1940s [42]. $E x_{s t}$ values increased from 1960 to the late 1970s. This increase follows the industrial fishery development in Mexico and Central America. Since 1953 total catches for the whole area had a sustained rate of increase [42]. In the late 1970s specific eco-exergy started to decline. The strong 1983-84 "El Niño" caused a severe drop in total catches of almost all species groups [42].

In the Indo(west)pacific (FAO areas 51, 57 and 71) area specific $E x_{s t}$ values did not undergo big changes. Values for specific eco-exergy in this area were between 461 and 478. In [32] it was found that "fishing down the food web" did not occur in this area and argued that the apparent stability is certainly due to inadequacies of the FAO statistics. There are numerous studies that document a similar species shift from high to low trophic levels as occurred in the northern temperate areas [2, 52-53]. Since the 1950s fishing industry grew and therefore specific eco-exergy increased. $E x_{s t}$ values decreased from the early 1960s till the late 1970s, in parallel with the rapid development of trawl fisheries in Southeast Asia in 1970s targeting shrimp for export. The increase of $E x_{s t}$ in the late 1970 s might be caused by the inadequate fishery statistics reflecting the increased landings of big fish. For example in the western Indian Ocean (FAO 51) a large increase of skipjack and yellowfin was reported since the early 80 s.

In the Antarctica (FAO areas 48, 58 and 88), from 1966 till 1972 only fish landings were reported. Therefore specific eco-exergy was constant and for this reason, it was not included in the statistical trend analysis. Fisheries quickly depleted bony fishes and $E x_{s t}$ values started to decrease. After the depletion of large fish, a considerable amount of landings were krill and therefore specific eco-exergy was low (Ex $x_{s t}$ for crustaceans is 232, see Table1). The Antarctica is the area with the biggest $E x_{s t}$ loss. 


\section{CONCLUSIONS AND FUTURE WORK}

There is a clear recognition that ecosystem-based fisheries management (EBFM) and related ecosystem approaches (EA) for marine systems are becoming increasingly important [54-57]. A key step to begin implementing EBFM is the development of tools to assess the status of large marine ecosystems, parallel to those used to assess populations of commercial valuable species [54].

Using $E x_{s t}$ to calculate the status of marine ecosystems seems to be such a tool as reflected from the data obtained by applying it to global fish catches data from FAO. With inshore, offshore- and distant-water fleets competing to supply increasingly integrated global markets, abundant species are exploited wherever they occur, and landings will tend to reflect their relative abundance. This was not the rule before fisheries became globalized and only selective species were exploited by near shore gear [58].

$E x_{s t}$ is a useful tool in environmental monitoring. Is quite easy to calculate and reflects the condition of an ecosystem as a whole $[20,59-60]$. The results with this indicator confirm the results obtained by [32] using the concept of mean trophic level. $E x_{s t}$ values have shown a continuous decline, from the 70's which extrapolated will give similar values of aquaculture $E x_{s t}$ in around 125 years. This value is in line with that from [3] who modeled the depletion of stocks as a function of time and predicted a $100 \%$ collapse for all currently fished taxa by the year 2048. However, as with all extrapolation techniques caution should be taken and they should be interpreted as a worse case scenario, since it is expected that fisheries policy would adapt to maintain a sustainable exploitation.

We have also applied statistical techniques to detect change of gradient at unknown time using likelihood ratio test, with the null hypothesis of linear relationship, to identify regime shifts and correlate them with well-known historical events in all defined FAO areas.

Nevertheless, it would be desirable to calculate specific eco-exergy on a higher taxonomic level $[26,31]$ and test the results with more detailed data sets. Presumably, using better taxonomic resolution, $E x_{s t}$ values would reflect the state of the ecosystem in more detail. Our research is continuing along these lines.

\section{ACKNOWLEDGEMENTS}

This research has been partially supported by the Integrated Project Thresholds of Environmental Sustainability (European Commission FP6, SUST-DEV, IP Project 003933-2).

\section{REFERENCES}

[1] Pauly D, Christensen V, Guénette S, Pitcher TJ, Sumalia UR, Walters CJ, Watson R, Zeller D. Towards sustainability in world fisheries. Nature 2002; 418: 689-695.

[2] Myers RA, Worm B. Rapid worldwide depletion of predatory fish communities. Nature 2003; 423: 280-283.

[3] Worm B, Barbier EB, Beaumont N, Duffy JE, Folke C, Halpern BS, Jackson JBC, Lotze HK, Micheli F, Palumbi S, Sala E, Selkoe KA, Stachowicz JJ, Watson R. Impacts of biodiversity loss on ocean ecosystem services. Science 2006; 314: 787-790.

[4] Beverton RJH, Holt SJ. On the dynamics of exploited fish populations. Chapman and Hall: London 1957.
[5] Roff DA. Analysis of catch/effort data: A comparison of three methods. Can J Fish Aquat Sci 1983; 40: 1496-1506.

[6] Shepherd JG. Fish stock assessments and their data requirements. In Gulland JA, Ed. Fish Population Dynamics. John Wiley \& Sons Ltd. 1998; 35-62.

[7] Hilborn R. Current and future trends in fisheries stock assessment and management. S Afr J Mar Sci 1992; 12: 975-988.

[8] Rosenberg AA, Restrepo VR. Uncertainty and risk-evaluation in stock assessment advice for US marine fisheries. Can J Fish Aquat Sci 1994; 51: 2715-2720.

[9] FAO. Towards ecosystem-based fisheries management.in The Reykjavik Conference on Resposible Fisheries in the Marine Ecosystem. 2001, Reykjavik October 1-4. (ftp: //ftp.fao.org/fi/document/reykjavik/Y1449E.doc)

[10] Daskalov G M. Overfishing drives a trophic cascade in the Black Sea. Mar Ecol Prog Ser 2002; 225: 53-63.

[11] Scheffer M., Carpenter SR, Foley JA, Folke C, Walker B. Catastrophic shifts in ecosystems. Nature 2001; 413: 591-596.

[12] Scheffer M, Carpenter SR. Catastrophic regime shifts in ecosystems: linking theory to observation. Trends Ecol Evol 2003; 18: 648-656.

[13] Mudarian, R. Ecological thresholds: a survey. Ecol Econ 2001; 38: 7-24.

[14] Huggett, AJ. The concept and utility of 'ecological thresholds' in biodiversity conservation. Biol Conserv 2005; 124: 301-310.

[15] Suter, GW. Ecological Risk Assessment. Lewis Publishers: Chelsea 1993.

[16] Resilience Alliance and Santa Fe Institute. 2004. Thresholds and alternate states in ecological and social-ecological systems. Resilience Alliance. http: //www.resalliance.org/index.php?id=183.

[17] Glantz MHD. Does history have a future? Forecasting climate change effects on fisheries by analogy. Fisheries 1990; 15: 39-44.

[18] Collie JS, Richardson K, Steele JH. Regime shifts: can ecological theory illuminate the mechanisms? Prog oceanogr 2004; 60: 281302.

[19] Frank KT, Petrie B, Choi JS, Legget WC. Trophic cascades in a formely cod-dominated ecosystem. Science 2005; 308: 1621-1623.

[20] Jørgensen SE. Integration of Ecosystem Theories: A Pattern. $2^{\text {nd }}$ ed. Kluwer: Dordrecht 1997.

[21] FAO, 2005, FishStat Plus: Universal software for fishery statistical time series (version 2.3) with the dataset "Capture production 1950-2003". http: //www.fao.org/fi/statist/FISOFT/FISHPLUS.asp. Data included in the dataset are published are published as "FAO yearbook. Fishery statistics. Capture production 2003. Vol. 96/1 (2005)". and "FAO yearbook. Fishery statistics. Aquaculture production 2003. Vol. 96/2 (2005)", FAO, Rome.

[22] Jørgensen SE, Ladegaard N, Debeljak M, Marques JC. Calculation of exergy for organisms. Ecol Modell 2004; 185: 165-175.

[23] Fonseca JC, Marques JC, Paiva AA, Freitas AM, Madeira VMC, Jørgensen SE. Nuclear DNA in the determination of weighing factors to estimate exergy from organisms biomass. Ecol Modell 2000; 126: $179-189$.

[24] Cavalier-Smith T. Introduction: The evolutionary significance of genome size. In: Cavalier-Smith T, Ed. The evolution of genome size. New York: John Wiley 1985; 1-36.

[25] De Wit R. Do all ecosystems maximize their distance with respect to thermodynamic equilibrium? A comment on the "Ecological law of thermodynamics" (ELT), proposed by Sven Erik Jørgensen. Sci Mar 2005; 69: 427-434.

[26] Austoni M, Giordani G, Viaroli P, Zaldivar JM. Application of specific exergy to macrophytes as an integrated index of environmental quality for coastal lagoons. Ecol Ind 2007; 7: 229-238.

[27] Souchu P, Ximenes M C, Lauret M, Vaquerand A, Dutriex E. Mise à jour d'indicateurs du niveau d'eutrophisation des milieux lagunaires méditerranéens. Ifremer-Créocean- Université Montpellier II, 2000.

[28] Orfanidis S, Panayotidis P, Stamatis N. Ecological evaluation of transitional and coastal waters: A marine benthic macrophytesbased model. Mediterranean Marine Science 2001; 2: 45-65.

[29] Orfanidis S, Panayotidis P, Stamatis N. An insight to the ecological evaluation index (EEI). Ecol Ind 2003; 3: 27-33.

[30] Kapraun DF. Nuclear DNA content estimates in multicellular eukaryotic green, red and brown algae: phylogenetic considerations. Ann Bot 2005; 95: 7- 44.

[31] Austoni M. Development and characterization of bio-indicators for Mediterranean coastal lagoons: Towards the application of specific 
exergy as an integrated indicator. Ph.D. diss., Dept of Environmental Sciences, Parma Univ 2007.

[32] Pauly D, Christensen V, Dalsgaard J, Froese R, Torres Jr F Fishing down marine food webs. Science 1998; 279: 860-863.

[33] Caddy JF, Csirke J, Garcia SM, Grainger R. Technical comments: How Pervasive is Fishing Down Marine Food Webs? Science 1998; 282: 1383.

[34] Watson R, Pauly D. Systematic distortions in world fisheries catch trends. Nature 2001; 414: 534-536.

[35] Rao CR. Linear Statistical Inference and Its Applications. Wiley: New York. 1965.

[36] Niwa H-S. Explotation dynamics of fish stocks. Ecol Informatics 2006; 1: 87-99.

[37] Zwanenburg KCT, Bundy A, Strain P, Bowen WD, Breeze H, Campana SE, Hannah C, Head E, Gordon D. Implications of ecosystem dynamics for the integrated management of Eastern Scotian Shelf. Can Tech Rep Fish Aquat Sci n 2652. Fisheries and Oceans, Canada 2006.

[38] Rana K, Immink A. Trends in Global Aquaculture Production: 1984-1996 (http: //www.fao.org/DOCREP/FIELD/006/AD742E/ AD742E00.HTM), 1996.

[39] Jaenike J. Comment on "Impacts of biodiversity loss on ocean ecosystem services". Science 2007; 316: 1285a.

[40] Wilberg MJ, Miller TJ. Comment on "Impacts of biodiversity loss on ocean ecosystem services". Science 2007; 316: 1285b.

[41] Hölker F, Beare D, Dröner H, di Natale A, Rätz H-J, Temming A, Casey J. Comment on "Impacts of biodiversity loss on ocean ecosystem services". Science 2007; 316: 1285c.

[42] FAO Marine Resources Service, Fishery Resources Division. Review of the state of world fishery resources: marine fisheries. FAO Fisheries Circular. No. 920. Rome, 1997. http: //www.fao.org/documents/show_cdr.asp?url_file=/docrep/003/w42 $48 \mathrm{e} / \mathrm{w} 4248 \mathrm{e} 00 . \mathrm{htm}$

[43] Report of the ICES Advisory Committee on Fishery Management. ICES Cooperative Research Report No. 214.ICE, Copenhagen. 1995.

[44] Brodziak J, Traver M, Col L, Sutherland S. Stock assessment of Georges Bank haddock, 1931-2004. Northeast Fisheries Science Center Ref. Doc. 06-11;2006.

[45] Magnuson JJ, Safina C, Sissenwine MP. Whose Fish Are They Anyway? Science 2001; 293: 1267-1268.

[46] Myers RA, Hutchings JA, Barrowman NJ. Why do fish stocks collapse? The example of cod in the Atlantic Canada. Ecol Appl 1997; 7: 91-106.
[47] Rose GA, deYoung B, Kulka DW,.Goddard SV, Fletcher GL. Distribution shifts and overfishing the northern cod (Gadus morhua): a view from the ocean. Can J Fish Aquat Sci 2000; 57: 644663.

[48] Lilly GR, Murphy EF, Healey BP, Maddock Parsons D, Stead R. An assessment of the Cod Stock in NAFO Divisions SJ + 3KL DFO, Can Sci Adv Sec Res Doc. 2001/044, 2001.

[49] Baum JK, Myers RA, Kehler DG, Worm B, Harley SJ, Doherty PA. Collapse and Conservation of Shark Population in the Northwest Atlantic, Science 2003; 299: 389-392.

[50] Lancelot C, Staneva J, Van Eeckhout D, Beckers JM, Stanev E. Modelling the Danube-influenced north-western continental shelf of the Black Sea. II. Ecosystem response to changes in nutrient delivery by the Danube river after its damming in 1972. Estuar Coast Shelf Sci 2002; 54: 473-499.

[51] Bearzi G, Politi E, Agazzi S, Azzellino A. Prey depletion caused by overfishing and decline of marine megafauna in eastern Ionian Sea costal waters (central Mediterranean). Biol Conserv 2006; 127: 373-382.

[52] Beddington JR, May RM. The harvesting of interacting species in a natural ecosystem. Sci Am 1982; 247: 42.

[53] Dalzell P, Pauly D. Assessment of the fish resources of Southeast Asia, with emphasis on the Banda and Arafura Sea. Neth J Sea Res 1999; 24: 641 .

[54] Link J. Does food web theory work for marine ecosystems? Mar Ecol Prog Ser 2002; 230: 1-9.

[55] FAO, Fisheries management. 2. The ecosystem approach to fisheries. FAO Technical Guidelines for responsible fisheries. FAO, Rome. 2003.

[56] Garcia SM, Leiva Moreno I. Global overview of marine fisheries. In: Sinclair M, Valdimarsson G, Eds. Responsible Fisheries in the Marine Ecosystem. FAO, Rome, 2003; pp.1-24.

[57] Browman HI, Stergiou KI. Perspectives on ecosystem based approaches to the management of marine resources. Mar Ecol Prog Ser 2004; 274: 296-303

[58] Pauly D, Froese R, Christensen V. Technical comments: How Pervasive is Fishing Down Marine Food Webs? Science 1988; 282: 1383.

[59] Jørgensen SE, Marques J, Nielsen SN. Structural changes in an estuary, described by models and using exergy as orientor. Ecoll Model 2002; 158: 233-240.

[60] Jørgensen SE, Ray S, Berec L, Straškraba M. Improved calibration of a eutrophic model by use of the size variation due to succession. Ecol Model 2002; 153: 269-277. 